\title{
Elucidation of thermotolerance diversity in cotton (Gossypium hirsutum L.) using physio-molecular approaches
}

\author{
R.M. Rana ${ }^{1}$, S.H. Khan ${ }^{1}$, Z. Ali ${ }^{2}$, A.I. Khan ${ }^{1}$ and I.A. Khan ${ }^{1}$ \\ ${ }^{1}$ Centre of Agricultural Biochemistry and Biotechnology, \\ University of Agriculture, Faisalabad, Pakistan \\ ${ }^{2}$ Department of Plant Breeding and Genetics, \\ University of Agriculture, Faisalabad, Pakistan \\ Corresponding author: R.M. Rana \\ E-mail: rashid_cabb@hotmail.com
}

Genet. Mol. Res. 10 (2): 1156-1167 (2011)

Received November 29, 2010

Accepted February 15, 2011

Published June 14, 2011

DOI 10.4238/vol10-2gmr1180

\begin{abstract}
Cotton (Gossypium hirsutum) is an important cash crop, but high temperature during its growing season is one of the major factors that limit its productivity. This problem compels plant breeders to breed for heat tolerance, which can help to overcome this challenge. It is very important to make a comprehensive screening of heat-tolerant genotypes so that only the best are chosen. Here we report the combined use of several techniques that can help breeders to screen their germplasm. Twelve cultivated cotton genotypes were evaluated for thermotolerance, using assays that included electrolyte leakage, chlorophyll accumulation and protein profiling, as well as RAPDs to assess genetic diversity. Two genotypes (B-557 and NIAB-78) showed tolerant behavior in three thermotolerance assays. RAPD analysis results showed maximum similarity in a range of $86.7-66.7 \%$ between the genotypes MNH-554 and CIM-443. We conclude that combined use should be made of relative electrolyte leakage, chlorophyll stability and differential display with SDS-PAGE to aid in screening for stress
\end{abstract}


tolerance. RAPD-based diversity analysis will further help to improve the efficiency of breeding programs.

Key words: Relative electrolyte leakage; Chlorophyll accumulation; SDS-PAGE; RAPD

\section{INTRODUCTION}

Cotton (Gossypium hirsutum L.) is a perennial plant and is very sensitive to adverse environmental conditions (Oosterhuis, 1997). Although it originated from hot climates, the ideal temperature for its growth and biomass accumulation is $20-30^{\circ} \mathrm{C}$. Temperature above the optimum is a major factor limiting crop production (Hall, 1992). However, no significant effect has been observed on the physiological functions of cotton up to $35-36^{\circ} \mathrm{C}$ (Bibi et al., 2008). High temperature has been reported in the literature as a major abiotic factor adversely affecting cotton yields (Oosterhuis, 2002). The temperatures higher than optimum, i.e., $>32^{\circ} \mathrm{C}$ adversely affect the reproductive efficacy of the crop in different ways, e.g., inhibition of photosynthesis, decreased metabolism, crop growth rate, pollination, and fertilization (Bibi et al., 2008; Snider et al., 2009), and increased respiration and photorespiration (Krieg, 1986). Environmental stress, including extremes of temperature and moisture, affect not only mature plants but also germinating seeds and seedlings as well. Failure to cope with such adverse effects results in poor seedling development and eventually reduced crop yields (Burke, 2001). High temperatures exceeding $45^{\circ} \mathrm{C}$ cause considerable damage to cotton plants and are a major concern to cotton physiologists and breeders working in stress environments.

Plants exposed to heat respond to a characteristic set of conserved cellular and metabolic processes. The heat stress causes a decrease in normal protein synthesis accompanied by an accelerated synthesis of new proteins known as heat shock proteins (HSPs). This response of plants is observed when they are exposed to temperatures at least $5^{\circ} \mathrm{C}$ above their optimal growing temperature. In addition to altering gene expression and protein synthesis patterns, heat also damages cellular structures including organelles and the cytoskeleton, and weakens membrane function resulting in retarded growth leading to organ injury and eventually plant death (Guy, 1999). The damage to membranes and different organs provides a selection basis for screening the germplasm into tolerant and susceptible ones, e.g., cell membrane thermostability (CMT). CMT developed by Sullivan (1972) had been used in heat tolerance studies on various crops, for example wheat (Saadalla et al., 1990), rice (Tripathy et al., 2000), soybean (Martineau et al., 1979), tomato (Moustafa et al., 2006) and cotton (Azhar et al., 2009). Chlorophyll synthesis and accumulation is also temperature sensitive and is a good indicator of heat stress injury. Burke and O'Mahony (2001) reported successful use of chlorophyll accumulation assay to assess the health of heat-treated cotyledons.

In addition to physiological indicators/markers of heat tolerance, molecular markers are also promising to help cotton screening and breeding phenomena aimed at improving its heat tolerance. Genetic diversity is a very important factor in breeding crops. The advent of molecular markers has facilitated characterization of the germplasm. Based on random amplification of DNA segments with single primers of arbitrary nucleotide sequence random amplified polymorphic DNA (RAPD) assay generates DNA profiles of varying complexity. RAPD analysis has been demonstrated in many applications and in various organisms espe- 
cially in the plant sciences (Sharma and Mohapatra, 1996) and was used successfully in field crops such as Iranian melon (Soltani et al., 2010), Brassica rapa (Wakui et al., 2009), cotton (Multani and Lyon, 1995; Chaudhary et al., 2010), etc.

The present study reports the use of relative electrolyte leakage as a measure of CMT, chlorophyll accumulation assay, protein, and RAPD profiling to assess their robustness of evaluation for thermotolerance response and genetic diversity in cotton crops. This combined approach can generate important information helpful in stress breeding programs.

\section{MATERIAL AND METHODS}

\section{Plant material and seed preparation}

Twelve cotton varieties/genotypes used for the analysis of thermotolerance are listed along with their pedigree in Table 1. Cottonseeds were delinted with concentrated $\mathrm{H}_{2} \mathrm{SO}_{4}$ for about $3 \mathrm{~min}$, washed thoroughly in sterile distilled water, surface sterilized with $0.1 \%$ solution of $\mathrm{HgCl}_{2}$ for $5 \mathrm{~min}$ and washed again thoroughly in sterile distilled water (Bhatti, 1974).

\begin{tabular}{|c|c|c|}
\hline Genotype & Pedigree & Year of release \\
\hline B-557 & $268 \mathrm{~F} \times(45 \mathrm{~F} \times \mathrm{LSS})$ & 1975 \\
\hline CIM-443 & (DPL 16 x AC 134-F1 30 kr) x (A89/FM x LRA-5166) & 1998 \\
\hline CIM-473 & $\begin{array}{l}{[\{\text { Coker } 8314 \times(124 \mathrm{~F} \times \text { Babdal })\} \times \text { x }\{\text { Coker } 100 \text { WA x }(\text { CIM } 46 \times x} \\
(\text { AC } 134 \times(\text { DPL } 16 \times \text { AC } 134-F 130 \mathrm{kr})))\}] \text { x LRA-5166 }\end{array}$ & 2002 \\
\hline CIM-496 & $(\mathrm{CIM}-70 \times$ CIM-158) $\times\{(\mathrm{W}-1104 \times \mathrm{S}-12) \times(\mathrm{CP}-15 / 2)\}$ & 2005 \\
\hline FH-682 & (B 557 x Ala (68)1) x Lankart 57 & 1992 \\
\hline FH-900 & (FH 672 x AET 5) x (B 557 x LRA 5166) & 2000 \\
\hline FH-901 & $\begin{array}{l}\{(\text { Coker } 8314 \times(124 \text { F x Babdal })) \times(\text { Coker } 100 \text { WA x W 1106 })\} \times \\
\{\text { W1104 x }((124 \text { F x Babdal }) \times(\text { MS } 39 \times \text { Mex }))\}\end{array}$ & 2000 \\
\hline FH-1000 & $\begin{array}{l}{[\{(124 \mathrm{~F} \times \text { Babdal }) \times(\text { MS } 39 \times \text { Mex 12) }\} \times 7203-14-4-A r i z o n a] \times} \\
{[\{(124 \text { F } \times \text { Babdal }) \times(\text { MS } 39 \times \text { Mex 12) }\} \times 7203-14-4-A r i z o n a]}\end{array}$ & 2003 \\
\hline MNH-554 & $\{(124 \mathrm{~F} \times$ Babdal $) \times(($ L $11 \times$ Lankart 57) $\times 4 C)\} \times\{(\mathrm{C} 603 \times$ Mex 3$) \times$ LRA-5166 $\}$ & 2000 \\
\hline NIAB-78 & (DPL $16 \times$ AC 134$)-F 1$ irradiated- $30 \mathrm{kr}$ gamma rays $(60 \mathrm{Co})$ & 1983 \\
\hline NIAB-111 & F1 seed 300 Gy gamma radiation & 2004 \\
\hline NIAB-999 & (DPL 16 x AC 134-F1 $30 \mathrm{kr}$ ) x LRA 5166 & 2003 \\
\hline
\end{tabular}

\section{Measurement of electrolyte leakage}

Electrolyte leakage was measured following the procedure of Ismail and Hall (1999). Leaf discs of $13 \mathrm{~mm}$ in diameter were harvested from 7-week-old plants grown in a glasshouse. A pair of leaf disc samples was collected early in the morning from both midrib sides of newly developed fully expanded leaves. Samples were collected in five replicates, one replicate from each plant and then pooled. Electrolytes, which either attached to the injured cells at the cut edge or adhered to the surface of leaf discs, were washed through rinsing in deionized water three times. Samples were incubated in $20 \mathrm{~mL}$ deionized water at room temperature. Electrical conductivity (EC) of the incubation solution was measured after $24 \mathrm{~h}\left(\mathrm{C}_{1}\right)$ by a dip cell EC meter (Model, HI-933300; Hanna Instruments, Woonsocket, MA, USA). Incubation solutions containing leaf discs were boiled in a water bath at $100^{\circ} \mathrm{C}$ for 45 min to disrupt the cells and leak their total electrolytes. Then, boiling samples were incubated at $25^{\circ} \mathrm{C}$ and after $24 \mathrm{~h}$ of incubation, $\mathrm{EC}$ was measured again $\left(\mathrm{C}_{2}\right)$. Relative electrolyte leakage was calculated using the following function (Moustafa et al., 2006): relative electrolyte leakage $=\left[\mathrm{C}_{1} / \mathrm{C}_{2}\right] \times 100$. 


\section{Chlorophyll accumulation assay}

Cotton seedlings of 12 genotypes were grown separately in an incubator in plastic pots $(250 \mathrm{~mL})$ with five seeds per pot. In total 12 genotypes were grown in 108 pots divided into three sets. Pots arranged following completely randomized design were placed at $35^{\circ} \mathrm{C}$ under dark conditions. On the fifth day of germination, the control seedling set $\left(\mathrm{T}_{0}\right)$ was transferred into a growth chamber maintained at $35^{\circ} \mathrm{C}$ and kept under continuous light for $36 \mathrm{~h}$. Second set of seedlings $\left(\mathrm{T}_{1}\right)$ was given heat treatment at $50^{\circ} \mathrm{C}$ for $30 \mathrm{~min}$, while a third set $\left(\mathrm{T}_{2}\right)$ was given a pre-incubation treatment of $40^{\circ} \mathrm{C}$ for $2 \mathrm{~h}$ followed by a heat shock treatment of $50^{\circ} \mathrm{C}$ for $30 \mathrm{~min}$. After treatment, $\mathrm{T}_{1}$ and $\mathrm{T}_{2}$ were transferred to continuous light for $36 \mathrm{~h}$ along with $\mathrm{T}_{0}$. Five cotyledons per genotype were collected and boiled in $80 \%$ acetone in a water bath for $1 \mathrm{~h}$ to extract the chlorophyll (Arnon 1949). Sample solution's absorption was measured at 645 and $663 \mathrm{~nm}$ using spectrophotometer (CECIL, CE 2021, Cambridge, UK). Chlorophyll ( $\mathrm{Chl} \mathrm{a}, \mathrm{Chl} \mathrm{b}$ and total $\mathrm{Chl})$ concentration was estimated using the following formulae, $\mathrm{Chl} \mathrm{a}(\mu \mathrm{g} / \mathrm{mL})=12.7(\mathrm{~A} 663)-2.69(\mathrm{~A} 645), \mathrm{Chl} \mathrm{b}(\mu \mathrm{g} / \mathrm{mL})=$ 22.9 (A645) - 4.68 (A663).

Total Chl $(\mu \mathrm{g} / \mathrm{mL})=20.2(\mathrm{~A} 645)+8.02(\mathrm{~A} 663)$ where, A645 and A663 is the solution's absorbance at 645 and $663 \mathrm{~nm}$, respectively. Chl a/b ratio was also calculated to assess the thermo-sensitivity of genotypes.

\section{Protein fingerprinting}

Twelve cotton genotypes were grown in plastic pots according to the procedure described in the preceding section of chlorophyll accumulation assay. On the 5th day of germination, the seedlings of respective sets were exposed to temperature regimes of 40,45 , and $50^{\circ} \mathrm{C}$ for $2 \mathrm{~h}$. After two hours of heat shock, heat-treated and untreated seedlings were sampled for protein isolation. The samples were immediately frozen using liquid nitrogen and stored at $-80^{\circ} \mathrm{C}$ until further analysis.

One gram which completes the seedling's tissues of each genotype was pulverized in protein extraction buffer [0.175 M Tris-HCl, $\mathrm{pH} 8.8 ; 5 \%$ sodium dodecyl sulfate (SDS); $15 \%$ glycerol; 0.3 M dithiothreitol (DTT)] to isolate total proteins. The whole of the pulverized sample of each genotype was obtained in $1.5-\mathrm{mL}$ microcentrifuge tubes separately and centrifuged at 13,000 rpm for $5 \mathrm{~min}$ in a bench-top microcentrifuge (MSB 010.CX1.5 MSE) to remove cell debris. The clear supernatant was transferred into a fresh tube and an equal amount of $20 \%$ trichloro-acetic acid was added. Samples were incubated on ice for $30 \mathrm{~min}$ and then centrifuged at 13,000 rpm for $15 \mathrm{~min}$. The supernatant was then carefully removed. The pellet was washed with ice cold $80 \%$ acetone, dried and re-suspended in 1X SDS polyacrylamide gel electrophoresis (PAGE) loading buffer [50 mM Tris-Cl, pH 6.8, 2\% SDS (w/v), 10\% glycerol (v/v), 0.1\% bromophenol blue and $100 \mathrm{mM}$ DTT]. Protein concentrations were estimated by the BioRad protein assay (Bradford, 1976). SDS-PAGE was performed in Bio-Rad Mini-Protean ${ }^{\mathrm{TM}}$ II apparatus (Bio-Rad Laboratories, Hemel Hempstead, UK) at $84 \mathrm{~V}$ for $2 \mathrm{~h}$ to resolve proteins. The gel was then stained for 2-4 h using Coomassie stain ( $0.1 \%$ Coomassie R-250, $10 \%$ acetic acid, $40 \%$ methanol) and subsequently destained using destaining solution ( $20 \%$ methanol, $10 \%$ acetic acid) for $4 \mathrm{~h}$ to overnight, changing destaining solution 3-4 times. Photographs of stained gels were taken and analyzed visually observing the patterns of protein bands. 


\section{Random amplified polymorphic DNA fingerprinting}

Genomic DNA from each genotype was isolated separately following Khan et al. (2004) and quantified by a spectrophotometer (CECIL CE 20212000 Series, Cambridge, UK) at $260 \mathrm{~nm}$. Quality of the isolated DNA was assessed on $0.8 \%$ agarose gel. The extracted DNA was diluted to a working concentration of $15 \mathrm{ng} / \mu \mathrm{L}$. The oligo-nucleotide decamer primers were obtained from GeneLink ${ }^{\mathrm{TM}}$ (GeneLink ${ }^{\mathrm{TM}}$ Company, Hawthorne, NY, USA). Twenty previously screened random decamer primers were selected based on their polymorphic nature. Polymerase chain reaction (PCR) mixtures $(25 \mu \mathrm{L})$ comprised of DNA template $(15 \mathrm{ng})$, Taq DNA polymerase (1 U), $\mathrm{KCl}(50 \mathrm{mM}), \mathrm{MgCl}_{2}(3 \mathrm{mM})$, dNTP $(100 \mu \mathrm{M}$ of each), 10X PCR buffer with $\left(\mathrm{NH}_{4}\right)_{2} \mathrm{SO}_{4}$, decamer primer $(0.2 \mu \mathrm{M})$. DNA amplification reaction was performed in thermo-cycler (Eppendorf AG No. 533300839, Germany). PCR cycling profile: hot start at $95^{\circ} \mathrm{C}$ for $5 \mathrm{~min}, 40$ cycles of $95^{\circ} \mathrm{C}$ for $1 \mathrm{~min}, 34^{\circ} \mathrm{C}$ for $1 \mathrm{~min}$ and $72^{\circ} \mathrm{C}$ for $2 \mathrm{~min}$, and a final extension at $72^{\circ} \mathrm{C}$ for $10 \mathrm{~min}$. PCR products were resolved on $1.2 \%(\mathrm{w} / \mathrm{v})$ agarose gel electrophoresis (with ethidium bromide, $10 \mathrm{ng} / 100 \mathrm{~mL}$ ). The fingerprints were examined under ultra-violet transilluminator (SynGen, Synoptics Ltd., Cambridge, UK) at $300 \mathrm{~nm}$.

Amplified DNA fragments were counted and designated as present (1) or absent (0). The data were collected and aligned for the construction of cluster analysis and similarity matrix using the PopGen software (Cambridge, UK) (version 1.44) based on Nei's unweighted paired group of arithmetic mean averages (Nei, 1972).

\section{Statistical analyses}

A principal coordinate analysis was conducted using RAPD data with GenAlEx 6.3. Mean and standard deviation were calculated from data of relative electrolyte leakage and chlorophyll.

\section{RESULTS}

\section{Relative electrolyte leakage}

The membrane damage was assessed indirectly by conductometric measurements of ion leakage from leaf cells and was calculated as a percentage of total electrolyte leakage. Percent electrolyte leakage ranges from 38.8 to $63 \%$ (Figure 1). Twelve genotypes were divided into three groups based on electrolyte leakage 1) $<40 \%$ (tolerant), 2) $40-50 \%$ (moderately tolerant), 3) $>50 \%$ (susceptible). Of 12 genotypes, four proved to be tolerant, five moderately tolerant and three susceptible.

\section{Chlorophyll accumulation}

Chlorophyll accumulation was measured at three levels: 1) $\mathrm{T}_{0}$ (control), 2) $\mathrm{T}_{1}$ (30-min treatment at $\left.\left.50^{\circ} \mathrm{C}\right), 3\right) \mathrm{T}_{2}\left(2\right.$-h pre-incubation at $40^{\circ} \mathrm{C}+30$-min treatment at $\left.50^{\circ} \mathrm{C}\right)$. Control seedlings accumulated total $\mathrm{Chl}(\mathrm{Chl} \mathrm{a}+\mathrm{Chl} \mathrm{b})$ in a range of 4.64 to $8.95 \mu \mathrm{g} / \mathrm{mL}(\mathrm{B}-557$ and NIAB-999, respectively) (Figure 2). However, the data showed general decrease in accumulation of total $\mathrm{Chl}$ at $\mathrm{T}_{1}$ and $\mathrm{T}_{2}$ in all genotypes. The $\mathrm{Chl} \mathrm{a} / \mathrm{b}$ ratio observed in control $\left(\mathrm{T}_{0}\right)$ seedlings was in a range of 2.91 to 1.86 (FH-901 and CIM-443, respectively) (Figure 3). 


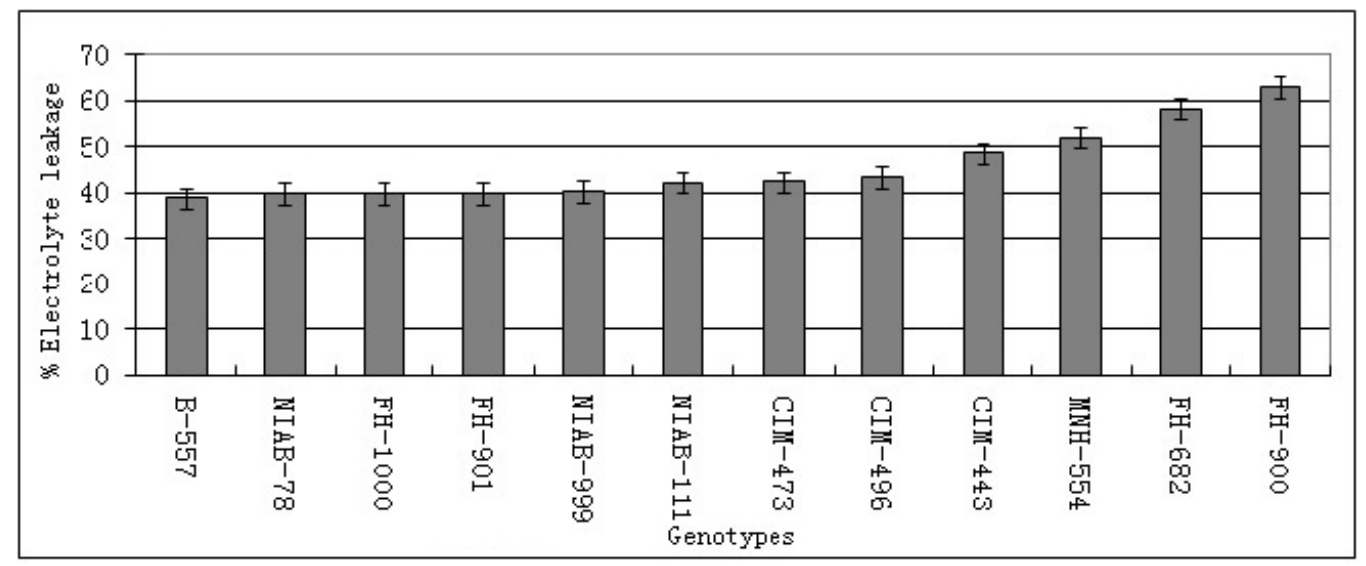

Figure 1. Relative electrolyte leakage (values are means from three replications and vertical bars indicate $\pm \mathrm{SEM}$ ).

Thermo-sensitivity in chlorophyll accumulation at $\mathrm{T}_{1}$ and $\mathrm{T}_{2}$ as compared to control seedlings was assessed by calculating the difference of respective $\mathrm{Chl} \mathrm{a} / \mathrm{b}$ ratios against the $\mathrm{Chl} \mathrm{a} / \mathrm{b}$ ratio of control $\left(\mathrm{T}_{0}\right)$ (Figure 4 ). The proportion of $\mathrm{Chl}$ a to $\mathrm{Chl} \mathrm{b}$ greatly depends on the chlorophyll thermostability of the species. Thus, the maximum increase was observed in FH-1000 $\left(0.311\right.$ at $\mathrm{T}_{1}$ and 0.282 at $\mathrm{T}_{2}$ ) while maximum decrease was found in CIM-443 (-0.170 at $\mathrm{T}_{1}$ and -0.179 at $\left.\mathrm{T}_{2}\right)$.

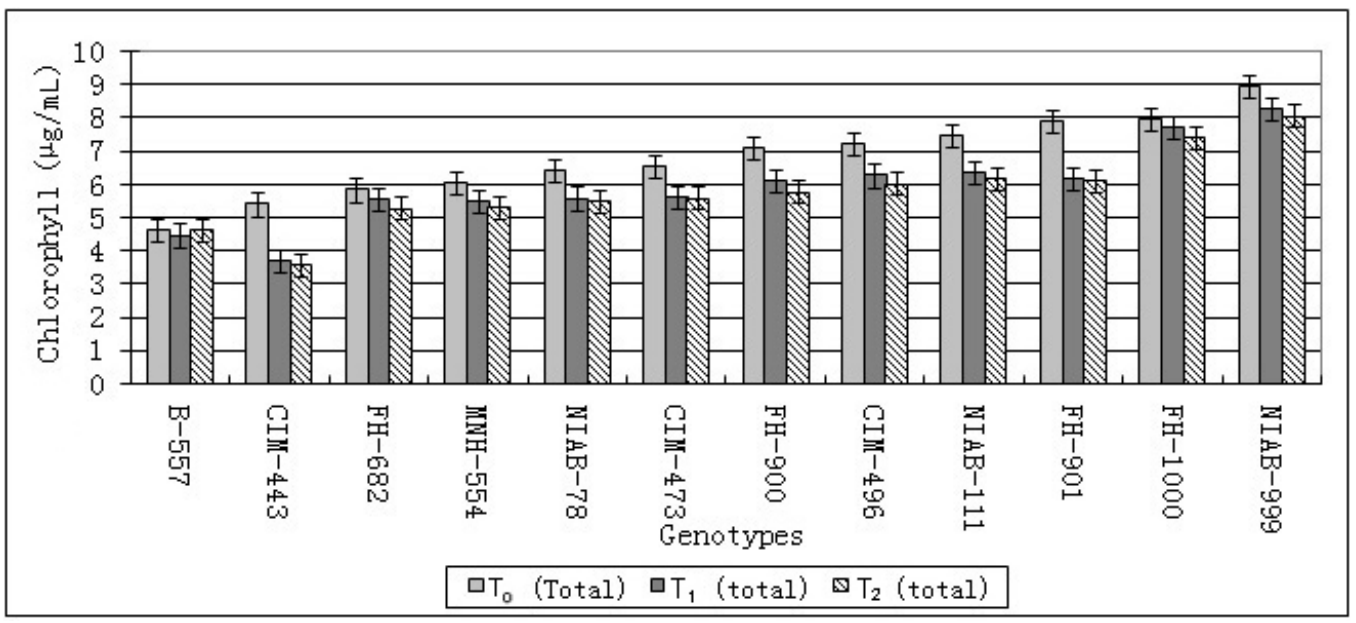

Figure 2. Comparison of genotypes using total chlorophyll $(\mathrm{a}+\mathrm{b})$ concentration $(\mu \mathrm{g}$ chlorophyll $/ \mathrm{mL})$ including $\mathrm{T}_{0}$, $\mathrm{T}_{1}$, and $\mathrm{T}_{2}$ (values are means from three replications and vertical bars indicate $\pm \mathrm{SEM}$ ).

\section{Protein profiling}

Equal amounts of proteins were extracted from seedlings with different heat shock treatments analyzed on SDS-PAGE. Protein profile shows a general decrease in the normal 


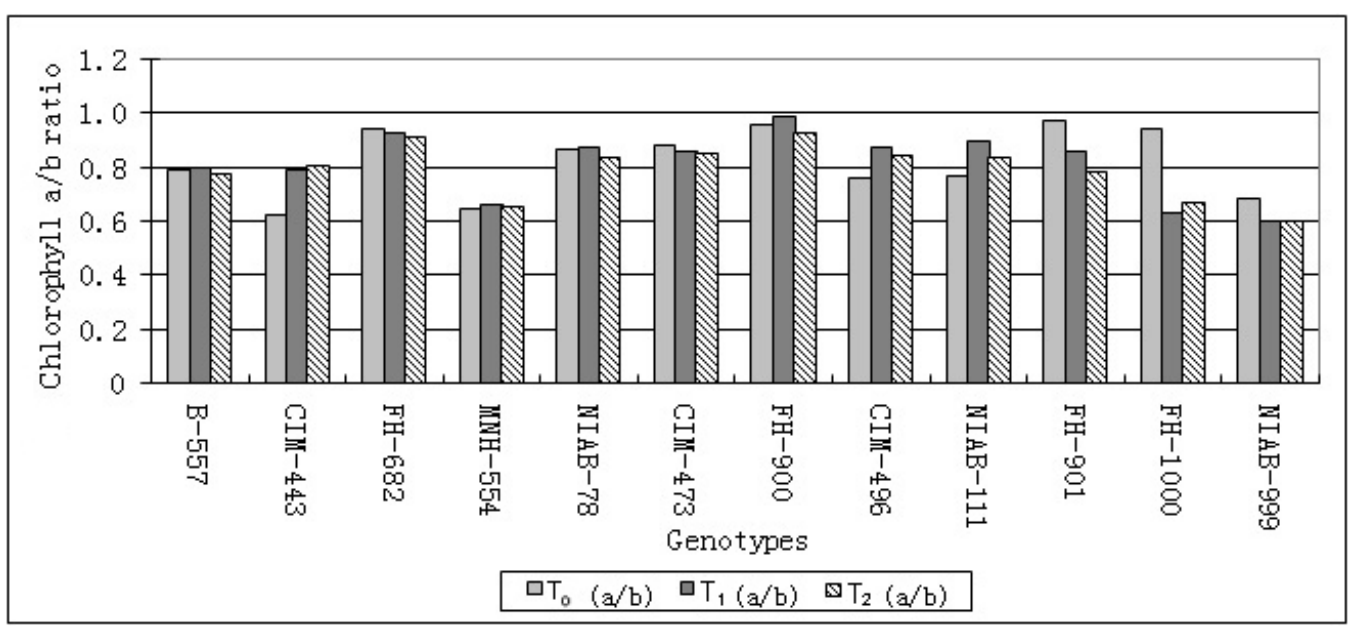

Figure 3. Comparison of genotypes using chlorophyll a/b ratio during different treatments.

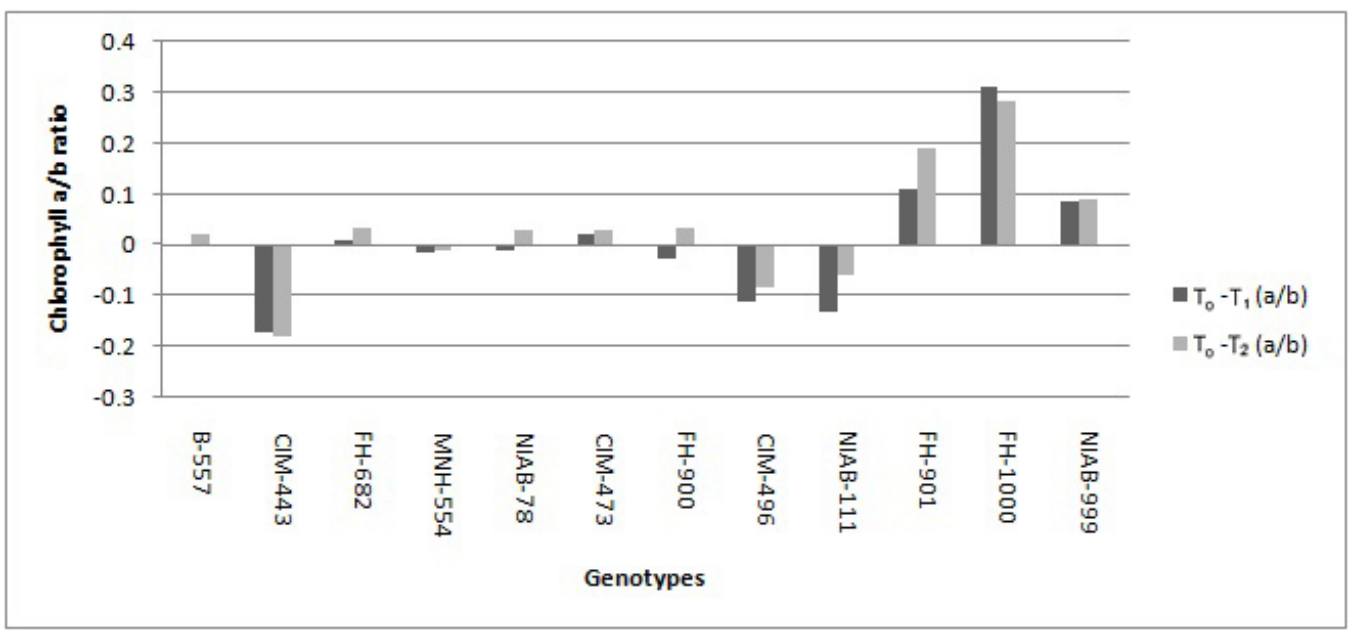

Figure 4. Difference of chlorophyll a/b ratio under stress treatments $\left(\mathrm{T}_{1}\right.$ and $\left.\mathrm{T}_{2}\right)$ as compared to control $\left(\mathrm{T}_{0}\right)$.

protein synthesis under high temperature in all varieties. Several new proteins had also appeared with an approximate molecular mass in the range of 24-36 kDa under stress conditions that were not present under control conditions (data not shown). However, the level of expression of these proteins in different cotton genotypes used in the study was different. Six genotypes (B-557, NIAB-78, FH-901, NIAB-111, FH-1000, and MNH-554) showed more accumulation of heat-induced proteins and lesser decrease in the expression of normal proteins while the remaining six genotypes showed a greater decrease in normal proteins and lesser expression of heat-induced proteins under stressed conditions. 


\section{RAPD profiling}

All 20 primers generated 90 bands with an average 4.5 bands per primer. Genotypes MNH-554 and CIM-443 showed a maximum similarity (86.67\%) while NIAB-111 and B-557 $(33.33 \%)$ were not diverse. An average genetic similarity observed in all genotypes was $76.67 \%$. Principle coordinate analysis divided 12 genotypes into three groups (Figure 5). A dendrogram obtained using Nei's similarity coefficient (Figure 6) represents grouping of all 12 genotypes into four clusters. Group A comprising three genotypes (CIM-443, MNH-554 and FH-1000), Group B four genotypes (CIM-473, B-557, FH-682, and FH-900), Group C two genotypes (NIAB-78 and NIAB-999), Group D two genotypes (CIM-496 and NIAB-111) while FH-901 did not cluster into any group.

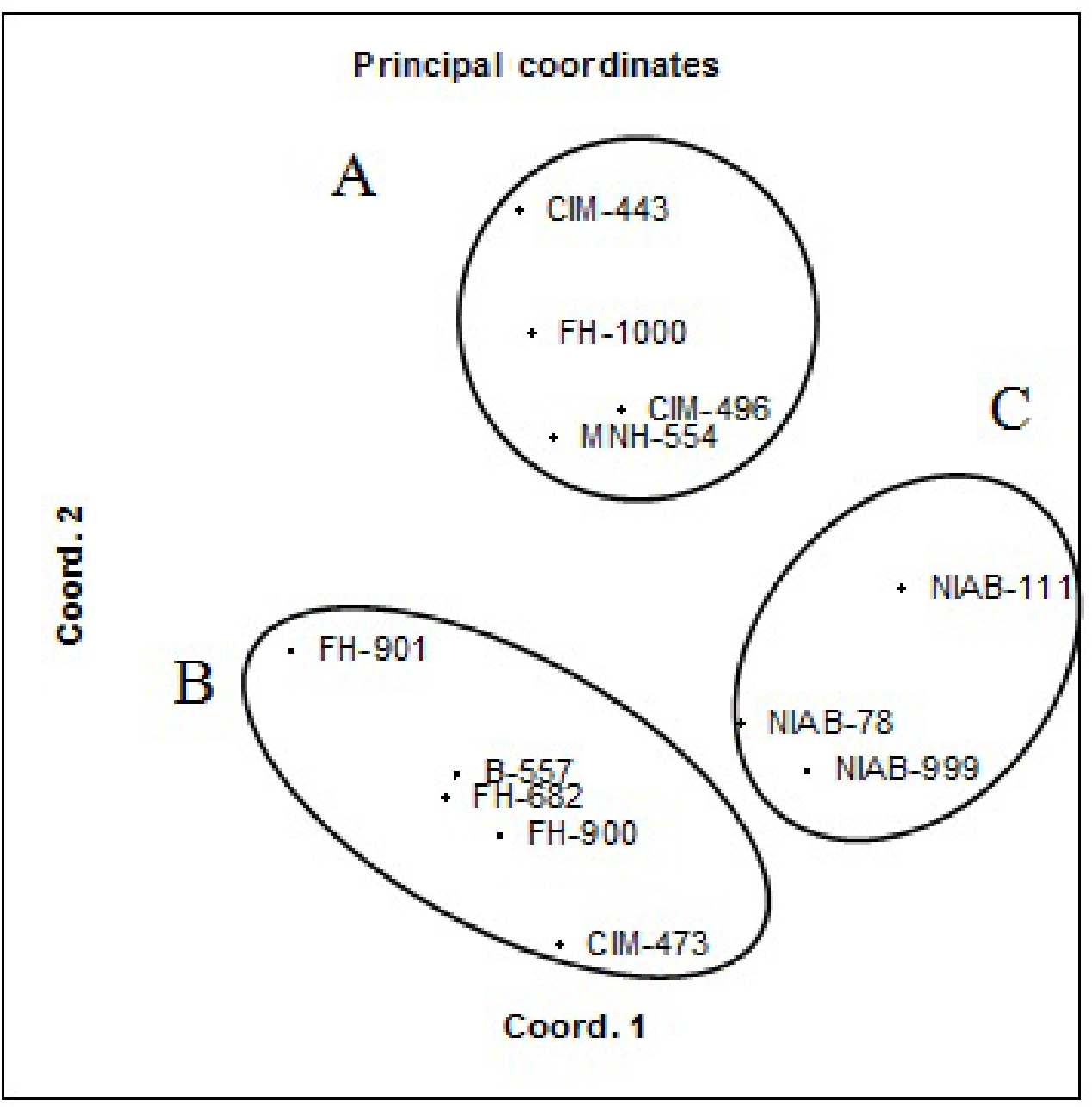

Figure 5. Associations between 12 genotypes on the basis of the first two principal coordinates (Coord. 1 and 2) obtained from a principal coordinate analysis of Jaccard similarity coefficients based on RAPD data. 


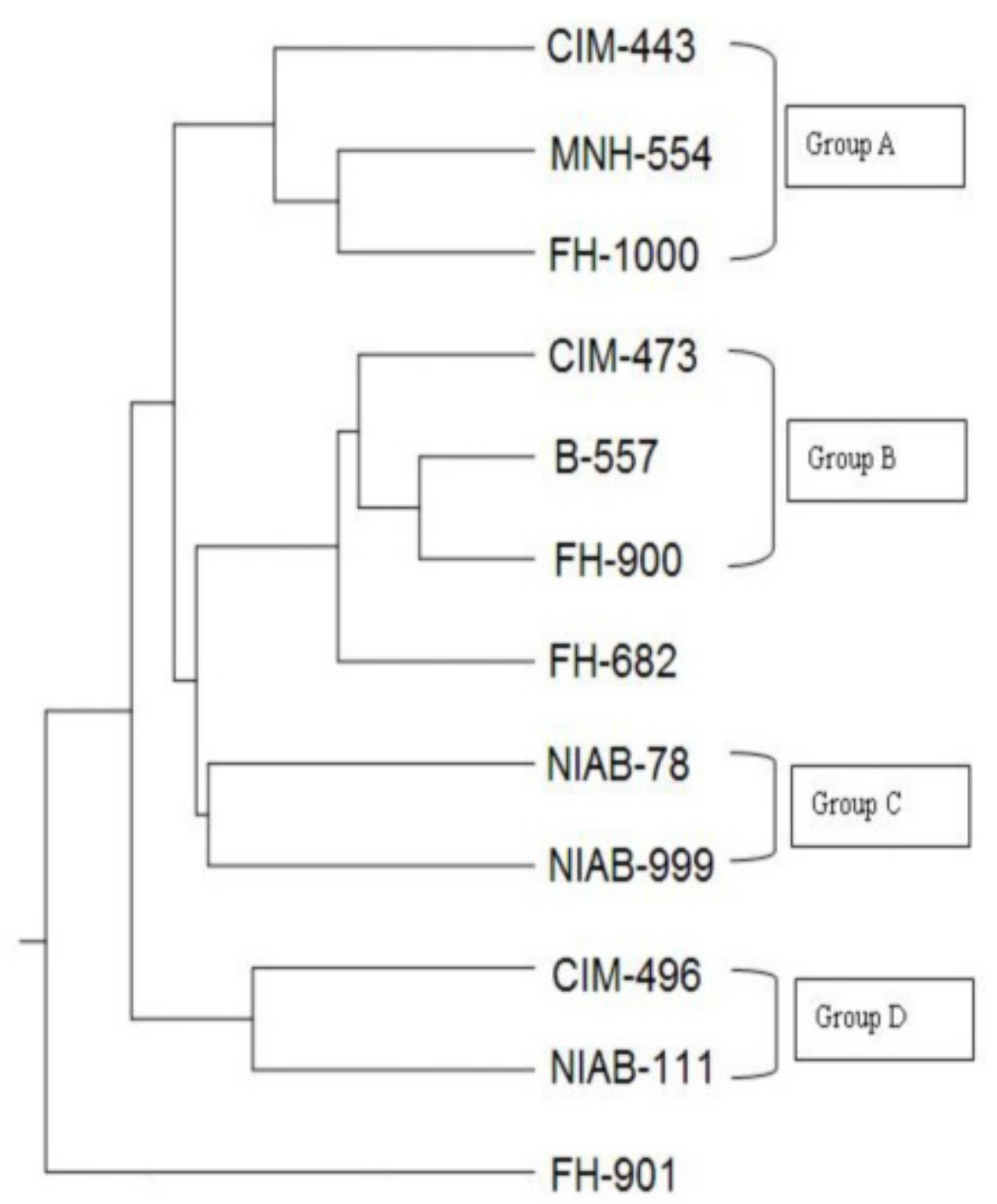

Figure 6. UPGMA dendrogram showing genetic relationships among the 12 cotton genotypes.

\section{DISCUSSION}

In Pakistan cotton (G. hirsutum L.) crop is sown in May and matures in September-November while the air temperature ranges from $45-50^{\circ} \mathrm{C}$, which is a common feature throughout the growing season. Under high temperature conditions, cotton seedlings have a poorly developed root system and adversely affect the leaves particularly the younger leaves (Lather et al., 2001). According to Hall (2001), when plants growing in pots are subjected to high air temperatures, both the shoots and the roots are exposed to hot conditions.

Screening of plant material for breeding is the basic requirement of any stress-breeding program to identify the suitable stock(s) (genotypes) for breeding. In the present study, we used 
physiological parameters like cell membrane thermostability, chlorophyll accumulation and protein profiling to assess the thermotolerant behavior of different cotton ( $G$. hirsutum L.) genotypes currently grown in Pakistan. RAPDs were used to characterize genotypes for genetic diversity.

Cell membrane thermostability was calculated as \% electrolyte leakage. Data of \% electrolyte leakage show that genotype B-557 was the most tolerant (38.8\% electrolyte leakage) and genotype FH-900 was the most sensitive (among the 12 genotypes used in this study) to heat stress $(63 \%)$. The results regarding genotypes B-557, FH-1000, NIAB-111, CIM-473, and CIM-496 reported as tolerant and MNH-554, FH-682 and FH-900 as susceptible are in concurrence with observations of Azhar et al. (2009). However, FH-901 previously reported as susceptible (Azhar et al., 2009) was found relatively tolerant in the present study.

Chlorophyll accumulation assay-generated data outline the chlorophyll content and $\mathrm{Chl}$ $\mathrm{a} / \mathrm{b}$ ratio in 12 cotton genotypes at two different stress levels $\left(\mathrm{T}_{1}\right.$ and $\left.\mathrm{T}_{2}\right)$ along with control. Although total chlorophyll exhibited a low content in B-557 it however shows a small difference in $\mathrm{Chl} \mathrm{a/b}$ ratio at different treatments as compared to controls (Figure 3). Other genotypes including FH-682, MNH-554, CIM-473, NIAB-78, and FH-900 were also nearly stable as regards their $\mathrm{Chl} \mathrm{a} / \mathrm{b}$ ratio. A decreased chlorophyll ratio in crop plants under drastic factor conditions shows increased resistance to heat and vice versa (El-Sharkawi and Salama, 1977). Therefore, these genotypes can be referred as tolerant/stable under temperature stress regarding chlorophyll accumulation. However, the $\mathrm{Chl} \mathrm{a} / \mathrm{b}$ ratio attained high values in remaining six genotypes. Santarius and Müller (1979) emphasized that the increase in the $\mathrm{Chl} \mathrm{a} / \mathrm{b}$ ratio caused by hardening is a feature of heat-sensitive genotypes. Cotton genotypes FH-1000, FH-901 and NIAB-999 showed a considerable increase whereas a maximum decrease was observed in CIM-443, CIM496 and NIAB-111; therefore, they can be referred to as sensitive and tolerant, respectively.

A general decrease in the synthesis of normal proteins has been previously observed accompanied by synthesis of thermo-tolerant proteins including HSPs (Key et al., 1981; Altschuler and Mascarenhas, 1982). The appearance of HSPs at high temperatures is a typical response to heat shock. Plants such as soybean, pea, maize, and wheat begin to synthesize small HSPs while exposed to temperatures above $32-33^{\circ} \mathrm{C}$ (Vierling, 1991). During SDS-PAGE analysis, besides a general decrease in normal proteins, we also observed some new proteins expressed in heat shock-treated seedlings. The estimated molecular weight of the proteins was in the range of 24-36 kDa, which may be correlated with the thermotolerance (Ledesma et al., 2004). Our observations are further supported by the observations of Ledesma et al. (2004) who observed the expression of 15- to $30 \mathrm{kDa}$ proteins in heat-treated strawberry plant leaves. Six cotton genotypes (B-557, NIAB-78, FH-901, NIAB-111, FH-1000, and MNH-554) showed more accumulation of heat-induced proteins and less decrease in the expression of normal proteins while the remaining six genotypes showed a greater decrease in normal proteins and less expression of heat-induced proteins under stressed conditions.

RAPD analysis shows that the genotypes MNH-554 and CIM-443 showed maximum similarity of $86.67 \%$. Average genetic similarity of $76.67 \%$ in the present instance is lower than the earlier report of $95.5 \%$ (Multani and Lyon, 1995) and higher than $67 \%$ (Chaudhary et al., 2010). Low genetic diversity is due to the narrow genetic base of the genotypes as Table 1 shows that most of the genotypes share at least one parent in common in their pedigrees. The genotypes clustered closer to each other in RAPD analysis share common or related parents (Figure 5). MNH-554 and CIM-443 clustered together and NIAB-999 and CIM-473 clustered closer to each other while they have LRA-5166 as a common parent.

Interestingly, although LRA-5166 was a common parent in four genotypes namely, 
MNH-554, CIM-443, NIAB-999 and CIM-473, they were not grouped into a single cluster. This phenomenon can be explained as they only have one common male parent, so the diversity due to female parent did not allow the four genotypes to cluster together. These results suggest the effective use of RAPD technique to determine genetic distance among cultivars as reported by Mukhtar et al. (2002).

Results from thermotolerance assays used in the study (relative electrolyte leakage, chlorophyll accumulation assay and SDS-PAGE profiling) show that 6 of 12 genotypes that have a tolerant behavior were common in at least 2 of the 3 assays. Two genotypes namely B-557 and NIAB-78 showed tolerant behavior in three assays. Our results are further supported by the results of Ashraf et al. (1994) who reported B-557 as tolerant to heat stress as it had lower relative injury and high seed germination under stress. Therefore, it is suggested that in combination with relative electrolyte leakage, chlorophyll stability and differential display using SDS-PAGE can further help breeders to choose the best single parents for stress breeding. The use of RAPD will further assist to use divergent cultivars in order to render the breeding program more successful.

\section{ACKNOWLEDGMENTS}

Research supported by the facilities provided by ALP-PARC research (project \#CS-108 batch 2) entitled "Molecular Characterization of Available Germplasm of Wheat in Pakistan" in CABB, UAF.

\section{REFERENCES}

Altschuler M and Mascarenhas JP (1982). Heat shock proteins and effects of heat shock in plants. Plant Mol. Biol. 1: 103-115.

Arnon DI (1949). Copper enzymes in isolated chloroplasts. Polyphenoloxidase in Beta vulgaris. Plant Physiol. 24: 1-15.

Ashraf M, Saeed MM and Qureshi MJ (1994). Tolerance to high temperature in cotton (Gossypium hirsutum L.) at initial growth stages. Environ. Exp. Bot. 34: 275-283.

Azhar FM, Ali Z, Akhtar MM, Khan AA, et al. (2009). Genetic variability of heat tolerance, and its effect on yield and fibre quality traits in upland cotton (Gossypium hirsutum L.). Plant Breed. 128: 356-362.

Bhatti AS (1974). Treatment of cotton seeds for germination. Plant and Soil 41: 681-683.

Bibi AC, Oosterhuis DM and Gonias ED (2008). Photosynthesis, quantum yield of photosystem II and membrane leakage as affected by high temperatures in cotton genotypes. J. Cotton Sci. 12: 150-159.

Bradford MM (1976). A rapid and sensitive method for the quantitation of microgram quantities of protein utilizing the principle of protein-dye binding. Anal. Biochem. 72: 248-254.

Burke JJ (2001). Identification of genetic diversity and mutations in higher plant acquired thermotolerance. Physiol. Plantarum 112: 167-170.

Burke JJ and O'Mahony PJ (2001). Protective role in acquired thermotolerance of developmentally regulated heat shock proteins in cotton seeds. J. Cotton Sci. 5: 174-183.

Chaudhary L, Sindhu A, Kumar M, Kumar R, et al. (2010). Estimation of genetic divergence among some cotton varieties by RAPD analysis. JPBCS 2: 039-043.

El-Sharkawi HM and Salama FM (1977). Effects of drought and salinity on some growth contributing parameters in wheat and barley. Plant and Soil 46: 423-433.

Guy C (1999). The Influence of Temperature Extremes on Gene Expression, Genomic Structure, and the Evolution of Induced Tolerance in Plants. In: Plant Responses to Environmental Stresses (Lerner HR, ed.). Marcel Dekker, New York, 497-548.

Hall AE (1992). Breeding for heat tolerance. Plant Breed. Rev. 10: 129-167.

Hall AE (2001). Consideration of Crop response to Environment in Plant Breeding. In: Crop Response to Environment. CRC Press LLC, Boca Raton, 197-208. 
Ismail AM and Hall AE (1999). Reproductive-stage heat tolerance, leaf membrane thermostability and plant morphology in Cowpea. Crop Sci. 39: 1762-1768.

Key JL, Lin CY and Chen YM (1981). Heat shock proteins in higher plants. PNAS 78: 3526-3530.

Khan IA, Awan FS, Ahmad A and Khan AA (2004). A modified mini-prep method for economical and rapid extraction of genomic DNA in plants. Plant Mol. Bio. Rep. 22: 89a-89c.

Krieg DR (1986). Feedback Control and Stress Effects on Photosynthesis. In: Proceedings of the Beltwide Cotton Conference. Natl. Cotton Counc. Am., Memphis, 227-243.

Lather BPS, Saini ML and Punia MS (2001). Hybrid cotton retrospect and prospects in Indian context. Nat. J. Plant Improv. 3: 61-68.

Ledesma NA, Kawabata S and Sugiama N (2004). Effect of high temperature on protein expression in strawberry plants. Biol. Plant. 48: 73-79.

Martineau JR, Specht JE, Williams JH and Sullivan CY (1979). Temperature tolerance in soybeans. I. Evaluation of a technique for assessing cellular membrane thermostability. Crop Sci. 19: 75-78.

Moustafa YMM, Yui S and Uemura M (2006). Chilling tolerance and field performance of an F1 cooking tomato cultivar, Nitaki-Koma, relative to its parents. Breed. Sci. 56: 269-276.

Mukhtar MS, Rahman M and Zafar Y (2002). Assessment of genetic diversity among wheat (Triticum aestivum L.) cultivars from a range of localities across Pakistan using random amplified polymorphic DNA (RAPD) analysis. Euphytica 128: 417-425.

Multani DS and Lyon BR (1995). Genetic fingerprinting of Australian cotton cultivars with RAPD markers. Genome 38: 1005-1008.

Nei M (1972). Genetic distance between populations. Am. Nat. 106: 283-292.

Oosterhuis DM (1997). Effects of Temperature Extremes on Cotton Yields in Arkansas. In: Proceeding of Cotton Research Meeting and Research Summaries (Oosterhuis DM, ed.). University of Arkansas Agricultural Experiment Station Special Report, Fayetteville, 94-98.

Oosterhuis DM (2002). Day or night high temperatures: a major cause of yield variability. Cott. Grow. 46: 8-9.

Saadalla MM, Shanahan JF and Quick JS (1990). Heat tolerance in winter wheat: hardening and genetic effect on membrane thermostability. Crop Sci. 30: 1243-1247.

Santarius KA and Müller M (1979). Investigation on heat resistance in spinach leaves. Planta 146: 529-538.

Sharma RP and Mohapatra T (1996). Molecular mapping and tagging of genes in crop plants. Genetica 97: 313-320.

Snider JL, Oosterhuis DM, Skulman BW and Kawakami EM (2009). Heat stress-induced limitations to reproductive success in Gossypium hirsutum. Physiol. Plant 137: 125-138.

Soltani F, Yukari A, Abdolkarim K, Zabihollah Z, et al. (2010). Characterization of Iranian melon landraces of Cucumis melo L. Groups Flexuosus and Dudaim by analysis of morphological characters and random amplified polymorphic DNA. Breed. Sci. 60: 34-45.

Sullivan CY (1972). Mechanisms of Heat and Drought Resistance in Grain Sorghum and Methods of Measurement. In: Sorghum in the Seventies (Rao NGP and House LR, eds.). Oxford \& IBH Publishing Co., New Delhi, 247-264.

Tripathy JN, Zhang J, Robin S, Nguyen TT, et al. (2000). QTLs for cell-membrane stability mapped in rice (Oryza sativa L.) under drought stress. Theor. Appl. Genet. 100: 1197-1202.

Vierling E (1991). The roles of heat shock proteins in plants. Annu. Rev. Plant Physiol. Plant Mol. Biol. 42: 579-620.

Wakui K, Iwata H, Takahashi Y, Takahata Y, et al. (2009). Assessment of the congruity of genetic relationships and variation revealed by individual- and bulked-samples-based approaches using RAPD and ISSR markers in Japanese turnip (Brassica rapa ssp. rapa) cultivars. Breed. Sci. 59: 447-452. 